\title{
Reduced reproductive success in voles Microtus arvalis and Myodes glareolus: Male presence negatively affects offspring survival and their growth rates
}

\author{
Vladimir S. Gromov
}

\begin{abstract}
The effect of the presence or absence of the male on pup survival and pup growth was measured from birth through day 30 after birth in the common vole (Microtus arvalis) and the bank vole (Myodes glareolus). It was found that the presence of the male can result in some decrease in the offspring survival in both species under study. In the common vole, the growth rates of pups reared by single females were significantly higher than in the pups reared by both parents, and the presence of the sire negatively affected the growth rates of the young males. As for the bank vole, the presence of the male was found to have no effect on the growth rates of the young individuals. The results of the study indicate a decrease in reproductive success, and, accordingly, in fitness, of males of the species under study, especially in the common vole, if they choose a reproductive strategy based on pair bonding and biparental care. Possible factors favoring the formation of family groups and increasing individual indirect fitness in social (biparental) rodent species are discussed.
\end{abstract}

How to cite this article: Gromov V.S. 2021. Reduced reproductive success in voles Microtus arvalis and Myodes glareolus: Male presence negatively affects offspring survival and their growth rates // Russian J. Theriol. Vol.20. No.1. P.11-18. doi: 10.15298/rusjtheriol.20.1.02.

KEY WORDS: Microtus arvalis, Myodes glareolus, male presence, growth rate, offspring survival.

Vladimir S. Gromov [vsgromov@mail.ru], A.N. Severtsov Institute of Ecology and Evolution, Russian Academy of Sciences, Leninsky pr. 33, Moscow 119071, Russia.

\section{Снижение репродуктивного потенциала у обыкновенной (Microtus arvalis) и рыжей (Myodes glareolus) полевок: присутствие самца негативно влияет на выживаемость и темпы роста детенышей}

\section{В.С. Громов}

РЕЗЮМЕ. У обыкновенной и рыжей полевок (Microtus arvalis и Myodes glareolus) оценивали эффект присутствия самца на выживаемость и темпы роста детенышей. Исследование показало, что у обоих видов присутствие самца может приводить к гибели части детенышей. У обыкновенной полевки темпы роста детенышей в группах, где присутствовал взрослый самец, были достоверно ниже, чем в группах, где детеныши находились только с матерью. Наибольшее снижение темпов роста отмечено у детенышей-самцов. У рыжей полевки присутствие самца не отражалось на темпах роста детенышей. Результаты исследования указывают на то, что репродуктивный успех и, соответственно, индивидуальная приспособленность самцов у исследованных видов, особенно у обыкновенной полевки, снижаются, если они придерживаются репродуктивной стратегии, связанной с формированием прочных парных связей и заботой о потомстве у обоих полов. Обсуждаются факторы, способствующие переходу от одиночного образа жизни к семейно-групповому и повышению индивидуальной приспособленности у социальных видов грызунов.

КЛЮЧЕВЫЕ СЛОВА: Microtus arvalis, Myodes glareolus, присутствие самца, темпы роста, выживаемость детенышей. 


\section{Introduction}

Males should attempt to mate with as many females as possible to maximize life-time reproductive success (Trivers, 1972). Moreover, males would forfeit potential reproductive success if they increased their parental effort in any one female's young at the expense of lost mating opportunities (Kurland \& Gaulin, 1984). In accordance with this reproductive strategy, males of most mammalian species avoid paternal responsibility. An alternative male reproductive strategy, that is, participation in care-giving activities, is characteristic of a relatively small number of mammalian species (Kleiman, 1977). Male care of young is thought to evolve, in part, because care-giving activities improve offspring survivorship to such an extent that the benefits of paternal investment outweigh the costs of lost mating opportunities (Gubernick \& Teferi, 2000; Curtis et al., 2007). Among rodents, paternal behavior is mostly expressed in species with long-lasting pair bonds and a family-group lifestyle (Eisenberg, 1966; Dudley, 1974a; Hartung \& Dewsbury, 1979; McGuire \& Novak, 1984; Gromov, 2013). In monogamous California mice, mated pairs were reported to be able to raise a litter of four pups, while females alone were able to raise litters of two pups only (Cantoni \& Brown, 1997). Besides, paternal presence significantly enhanced offspring survival in this species (Gubernick \& Teferi, 2000). However, other experimental studies on rodents have shown that male presence had little or no effect on the survival, growth, and development of most species studied in laboratory or semi-natural environments (Dudley, 1974b; Ahroon \& Fidura 1976; Elwood \& Broom, 1978; Gerling \& Yahr, 1979; Adler et al., 1987; Salo \& French, 1989; WynneEdwards \& Lisk, 1989; Gubernick et al., 1993; Wang \& Novak, 1994a, 1994b; Schradin \& Pillay, 2005; McGuire $\&$ Bemis, 2007). Hence, the adaptive significance of rodent male care, as well as the effect of male presence, remains unclear, and assumptions concerning its benefits to offspring need to be additionally tested on more species exhibiting paternal responsiveness.

The subjects of the present study are the common vole, Microtus arvalis Pallas, 1778, and the bank vole, Myodes (= Clethrionomys) glareolus Schreber, 1780. The common vole is a species whose competitive relationships between males, expressed in a dominance hierarchy, are combined with biparental care (Bashenina, 1962; Zorenko, 1979; De Jonge, 1983; Gromov, 2013). Specifically, the common vole males display such care-giving activities as retrieving, grooming, and huddling over pups. In a previous study (Gromov \& Voznesenskaya, 2013), it was shown that participation of males in the care-giving activities depends on their social status related in turn to the level of androgens. Dominant males, characterized by higher levels of testosterone and, consequently, increased levels of aggression, are inferior in parental care to less-aggressive subordinate males with lowered androgen secretion. It should be also noted that paternal care expressed by a mature male is the main factor of epigenetic programming of the behavioral responses in offspring. Specifically, the absence of a male may negatively affect the development of the behavior ensuring pair bonding and paternal care in young males having reached sexual maturity (Gromov, 2013, 2020a). On the other hand, males' fitness expressed in accelerated growth rates of their offspring appeared to be higher, and biparental care may result in increased offspring size relative to offspring reared by a single female. Larger body size at weaning may result in some potential benefits. For example, offspring that are heavier at weaning survive better than offspring that are lighter at weaning (Solomon, 1991). Besides, offspring that are heavier at weaning tend to be heavier as adults. The latter are preferred as social, and presuming as sexual, partners (Solomon, 1993). In the common vole, one could expect that the presence of the male would have a positive effect on survival and growth rates of the offspring thus enhancing the male fitness.

As for the bank vole, this is a species with dominance hierarchy among males competing for receptive females and primarily sole maternal care (Bujalska, 1994; Chistova, 1998; Bujalska \& Saitho, 2000; Opperbeck et al., 2012). However, some bank vole males exhibit direct paternal care in captivity; in particular, they display retrieving pups (Gromov \& Osadchuk, 2013). Nevertheless, one could expect a negative effect of the presence of the male on survival and growth rates of the offspring in the bank vole because males of this species are prone to be infanticidal.

Thus, the main goal of the present study is to determine whether the presence of the male affects (and, if so, how) survival and growth rates of the offspring in the common vole and the bank vole - two rodent species with generally different reproductive strategies.

\section{Materials and methods}

Housing conditions of rodents bred in captivity for a long time considerably affect the parental behavior of males (McCarty \& Southwick, 1977; Hartung \& Dewsbury, 1979; Xia \& Millar, 1988; Gromov, 2013). In the present study, litters were obtained from individuals captured in a natural population to avoid this effect. The rodents under study were trapped in May-June 2018 in the environs of the Chernogolovka Field Station (ChFS) of the Severtsov Institute of Ecology and Evolution (Moscow region) in a derelict agricultural field (common voles) and a mixed forest (bank voles) using live-traps baited with bread and vegetable oil. In both biotopes, the live-traps were arranged in two lines (each containing 50 traps with a ten-meter interval) located at a distance of about $500 \mathrm{~m}$ between them.

Mature individuals only were used for the study. To avoid the effect of familiarity, the breeding pairs of the voles were formed of the individuals captured in different lines of the live-traps and placed in their breeding cages immediately after trapping. The animals were kept in the ChFS vivarium in plastic cages $(60 \times 35 \times 20 \mathrm{~cm})$ with woodchip bedding topped with some hay for nesting. The vivarium had a natural (unregulated) illumination, and 
the temperature inside was $20 \pm 3^{\circ} \mathrm{C}$. The voles were fed on mixture of oats, sunflower seeds and shelled walnuts, as well as fresh vegetables (carrot, cabbage, beetroots), fresh dandelion greens and water were provided $a d l i b$. The females were examined daily over 15 days after the pairs were formed to detect pregnancy and pup births in time. The pairs successfully reproduced: the number of pups ranged from 4 to 8 per litter in the common vole, and from 5 to 10 per litter in the bank vole. In the common vole, all the females were found to be pregnant during two weeks after formation of the breeding pairs. In the bank vole, the same was observed during a month after formation of breeding pairs. All the pups under study were born at the period from mid June to late July.

In the common vole, two litter groups (I and II) comprising 130 pups were observed. In experimental group I (11 litters, 65 pups), the females reared their offspring in the absence of the males which were set apart 3-5 days before the birth of pups. In experimental group II (11 litters, 65 pups), the young was raised by both parents. In five females of this experimental group, the second pregnancy occurred, following postpartum estrus and mating with males. The newborn pups from the second litters were removed to avoid their possible negative influence on the growth of the young individuals from the first litters.

In the bank vole, also two litter groups (III and IV) comprising 129 pups were observed. In experimental group III (10 litters, 66 pups), the females reared their offspring in the absence of the males which were set apart 3-5 days before the birth of pups. In experimental group IV (10 litters, 63 pups), the young was raised by both parents. Second pregnancy was not detected in females of this experimental group.

The growth rates of the pups were assessed by their weighing on the day of birth and subsequently at the age of 12,21 , and 30 days. The indicated age classes are important for many vole species: 12 days - age of vision development, starting solid food intake, and young individuals coming out of the burrows; 21 days - age of weaning and onset of sexual maturation in females; 30 days is the age at which young individuals are ready to dispersal (Bashenina \& Meyer, 1994; Bashenina et al., 1994).

The newborn pups and, subsequently, young individuals were weighed with a laboratory scale CAS MWP-300 with a precision balance of $0.1 \mathrm{~g}$. Weighing was carried out at the same time - from 12:00 to 13:00. The growth rates of the pups were analyzed separately in the species under study (i.e., no inter-species statistical comparison was performed). Each sample was examined for fitting to normal distribution $\left(\chi^{2}\right.$-test) prior to statistical analysis. Main effects ANOVA was used to assess differences between the samples in the body mass of newborn pups and young individuals, with two categorical factors: "experimental group" and "litter". To assess difference in litter size between the samples, one-way ANOVA was used. Proportions of litters with different rates of juvenile mortality were examined with $2 \times 2 \chi^{2}$ analysis (Sokal \& Rohlf, 1995).
Compliance with ethical standards. All applicable inter-national, national, and/or institutional guidelines for the care and use of animals were followed.

\section{Results}

\section{The common vole}

The average numbers of the newborn pups in experimental groups I (without males) and II (with both parents) were practically the same: $5.9 \pm 0.2$ and $5.9 \pm 0.3$, respectively $(F=0.001, d f=20, p=0.999)$. The results of examination of the samples characterizing the body mass of the young from different age classes for their fitting to normal distribution were positive: $10.691<\chi^{2}$ $<36.021, p<0.030$.

The pup body mass at birth was the same in both experimental groups and averaged $2.1 \pm 0.1 \mathrm{~g}(F=1.181$, $d f=1 / 18, p=0.279)$. Thus, no significant differences in litter size or the pup body mass at birth were detected between the compared samples.

The pup survival rate in experimental group I was $100 \%$, while death of five pups aged less than 12 days was recorded in three of 11 litters $(27.3 \%)$ in experimental group II. Comparison of these proportions with $2 \times 2$ $\chi^{2}$ analysis revealed a significant difference: $\chi^{2}=31.21$, $d f=1, p<0.001$.

No significant difference in the body mass of the pups reared by females from experimental group II, irrespective of whether the second pregnancy associated with postpartum estrus occurred or not, was detected between three age subgroups $(12,21$ and 30 days) $(0.531<F<3.030, d f=1 / 48,0.087<p<0.469)$. Therefore, the second pregnancy had no effect of the rate of the pups' growth.

Table contains data characterizing the growth rates of the pups in experimental groups I and II. No essential difference in the mean body mass of pups reaching the age of 12 days was found $(F=2.27, d f=1 / 110, p=$ 0.135 ). Subsequent weighing (at the age of 21 days) showed that young individuals in experimental group I were characterized by the greater body mass (on average $15.3 \pm 0.1 \mathrm{~g})$, when compared with those in experimental group II (on average $14.7 \pm 0.2 \mathrm{~g})(F=9.96, d f=1 / 109$, $p=0.002)$. At the age of 30 days, the difference was more distinct; the body mass of young individuals in experimental groups I and II averaged $19.7 \pm 0.2 \mathrm{~g}$ and $18.3 \pm 0.4 \mathrm{~g}$, respectively $(F=24.56, d f=1 / 109, p<$ $0.001)$. The young males showed a greater difference: at the age of 30 days, their body mass in experimental groups I and II averaged $20.1 \pm 0.4 \mathrm{~g}(n=38)$ and $18.3 \pm$ $0.3 \mathrm{~g}(n=31)$, respectively $(F=27.93, d f=1 / 52, p<$ $0.001)$, while the difference in the mean body mass of females in experimental groups I and II was not significant: $19.2 \pm 0.5 \mathrm{~g}(n=34)$ and $18.3 \pm 0.5 \mathrm{~g}(n=31)$, respectively $(F=1.97, d f=1 / 45, p=0.168)$. Therefore, the growth rate of pups reared by females in the absence of the males was higher than in the pups reared by both parents, and the presence of the male negatively affected the growth rate of the young males. 
Table. The mean body mass $(\mathrm{g} \pm \mathrm{SE})$ of newborn pups and young individuals of different age classes in two vole species (M. arvalis and M. glareolus) in experimental groups without males (I, III) and with both parents (II, IV).

\begin{tabular}{|c|c|c|c|c|c|c|}
\hline \multicolumn{4}{|c|}{ M. arvalis } & \multicolumn{3}{c|}{ M. glareolus } \\
\hline Age & Group I & Group II & $p^{*}$ & Group III & Group IV & $p^{*}$ \\
\hline Newborn & $2.1 \pm 0.1$ & $2.1 \pm 0.1$ & NS & $1.7 \pm 0.1$ & $1.8 \pm 0.1$ & NS \\
\hline 12 days & $8.0 \pm 0.1$ & $8.3 \pm 0.2$ & NS & $6.1 \pm 0.1$ & $6.2 \pm 0.1$ & NS \\
\hline 21 day & $15.3 \pm 0.1$ & $14.7 \pm 0.2$ & 0.002 & $10.8 \pm 0.2$ & $10.5 \pm 0.1$ & NS \\
\hline 30 days & $19.7 \pm 0.2$ & $18.3 \pm 0.4$ & $<0.001$ & $14.4 \pm 0.1$ & $13.9 \pm 0.1$ & NS \\
\hline
\end{tabular}

* significance levels after Main effects ANOVA test

The bank vole

The numbers of the newborn pups in experimental groups III (without males) and IV (with both parents) averaged $6.6 \pm 0.3$ and $6.3 \pm 0.5$, respectively, and the difference is not significant (one-way ANOVA, $F=0.222$, $d f=18, p=0.643)$. The results of examination of the samples characterizing the body mass of the young from different age classes for their fitting to normal distribution were positive: $11.389<\chi^{2}<61.279, p<0.001$.

The pup body mass at birth in experimental groups III and IV averaged $1.7 \pm 0.1 \mathrm{~g}$ and $1.8 \pm 0.1 \mathrm{~g}$, respectively, and the difference is not reliable: $F=0.011, d f=1 / 117$, $p=0.914$. Thus, there were no significant differences in litter size and the pup body mass at birth between the compared samples.

In experimental group III, death of only two newborn pups in two (largest) of ten litters $(20 \%)$ was detected, while in experimental group IV death of 11 pups aged less than 12 days was recorded in five of ten litters $(50 \%)$. Comparison of these proportions with $2 \times 2 \chi^{2}$ analysis revealed a significant difference: $\chi^{2}=19.78, d f=1$, $p<0.001$.

Data characterizing the growth rates of the pups in experimental groups III and IV are shown in table. No significant differences were recorded in young individuals of all age classes $(1.071<F<2.510, d f=$ $1 / 105,0.116<p<0.303)$. Therefore, the growth rates of the young bank voles were found to be not affected by the presence of the male.

\section{Discussion}

It is now generally accepted that the ancestral condition for all mammalian groups is of solitary individuals (Lukas \& Clutton-Brock, 2013). For most rodent species, the occurrence of paternal care is a very unusual situation in the wild. A small part of rodents species only live in family groups exhibiting long-lasting pair bonds and biparental care of young (Gromov, 2011c, 2013). In rodents, paternal care is thought to evolve because care by males increases male reproductive success through increased survival and enhanced development of offspring. Such effects on offspring may result directly from paternal care or indirectly from enhanced maternal condition as a result of reduced maternal workload and more time spent foraging.
As previously indicated, common vole males can take an active part (at least in captivity) in care of their offspring (De Jonge, 1983; Gromov, 2011c, 2013). Direct care of young is also observed in some bank vole males captured in the wild (Gromov \& Osadchuk, 2013). However, a positive effect of the presence of the male on survival and growth rates of the offspring was not revealed in the present study even in the common vole. In contrast, it was found that the male presence may negatively affect the offspring survival. Besides, young common voles, especially males, raised by both parents showed a significant decrease in their growth rates. These findings indicate that biparental care may result in reduced reproductive success in the common vole, at least under laboratory conditions.

It is generally accepted that group living, or sociality, is an evolved strategy to increase inclusive fitness (Hamilton, 1964). Socioecological conceptual models accounting for the evolution of sociality in rodents suggest specific reproductive tactics enhancing fitness of individuals living in groups (Emlen, 1991, 1994; Lacey \& Sherman, 1997, 2007). Since the species with a family-group lifestyle are at the top of rodent sociality (Gromov, 2013, 2014a, 2018), one can expect that the long-term pair bonds as well as biparental care that are typical reproductive tactics of many social rodent species would maximize fitness of the members of family groups. However, such expectations are often not justified. In particular, studies in some Marmota species living in family groups (Blumstein \& Armitage, 1998) showed that sociality has its costs in terms of the ability to produce offspring. Specifically, a reduction in the annual per capita number of offspring produced was found in social marmots. Similar costs of sociality associated with a decrease in fitness were found in other social rodents - Cynomys ludovicianus Ord, 1815, and Ctenomys sociabilis Pearson et Christie, 1985: the litter sizes were shown to be reduced with an increase in the number of individuals in their groups (Hoogland, 1995; Lacey, 2004). Among muroid rodents, potential reproductive success of species with a family-group lifestyle was found to be also lower, especially in terms of litter size, when compared to solitary or gregarious species (Gromov, 2020b). The litter size variation could be related to the habitat effect (see, for example, Eisenberg, 1966): stable environmental conditions determine the formation of family groups associated 
with the tendency towards decreased litter size. On the contrary, under variable environments or unpredictable habitat, a less complicated social organization is formed in solitary and gregarious species whose reproduction success in terms of litter size is much higher. It should be noted, however, that not only environments but also other factors, in particular the presence of the males, may have a negative impact on the survival and growth rates of juveniles. This is confirmed by both the results of the present study and the data published earlier (Calhoun, 1962; Ahroon \& Fidura, 1976; Klippel, 1979; Lonstein \& De Vries, 1999). In other words, a family-group lifestyle seems to negatively affect reproductive success (i.e., fitness) in rodents.

The negative effect of the presence of the male on survival and growth rates of the offspring in the common vole could be explained, on the one hand, by the fact that a family-group lifestyle in this species has not fully developed yet (in terms of the evolution of sociality), and it has distinctive attributes of the social organization of less social species whose males avoid parental responsibility. In other words, this negative effect may be considered a peculiar "heritage" of the social structure typical of less social species forming aggregations (multi-male-multi-female breeding colonies) of adult individuals like, for example, in populations of the bank vole (Bujalska \& Saitho, 2000). On the other hand, the presence of the male may result in pup mortality and a decrease in their growth rates even in species with a typical family-group social organization and biparental care (Ahroon \& Fidura, 1976; Klippel, 1979, Lonstein \& De Vries, 1999). Any way, the negative effect found in the present study is not uncommon. The explanation of such a negative effect is not yet fully understood, and this phenomenon requires further examination. Perhaps, the presence of the male may interfere with the maternal care of young, so pups receive less maternal nursing, heating and grooming that in turn can lead to death of some juveniles and negatively affect the development and growth rates of the others.

As for the bank vole, it is not surprising that the presence of the male can result in lower offspring survival because males of gregarious species (like the bank vole) usually do not exhibit direct care of young and are prone to be infanticidal (Krebs et al., 2007; Gromov \& Osadchuk, 2013). Death of some pups in large litters raised by single females can also occur because of deficiency of milk produced by the females. In the wild and under semi-natural conditions, bank vole females defend pups against males and prevent their intrusion into the nest burrows (O.V. Osipova, personal communication). But under laboratory conditions (with a very limited space in small breeding cages), males have an opportunity to kill some pups when the female is out of the nest. Nevertheless, the experimental situation could be considered as a model of behavior of breeding pairs in a rodent species whose social organization transforms in the direction to a family-group lifestyle characterized by cohabitation of mating partners in a common burrow. On the first stage of this transformation, one can expect that the presence of the male may negatively affect both survival and growth rates of the offspring.

If a family-group lifestyle can negatively affect direct fitness, the following question arises: what are the factors favoring the formation of family groups in social rodent species? To answer this question, it is necessary to identify the key features of the rodent family-group lifestyle which is characterized, first and foremost, by long-term pair bonds, tolerant relationships between members of the family group, participation of males in care-giving activities, and cooperation in different activities related, for example, to defense and scent marking of the home range, digging underground tunnels, constructing nests and other shelters, foraging, food hoarding, etc. (Gromov, 2013, 2014a, 2018). The selective factors contributing to the evolutionary transition from solitary living to a family-group lifestyle are not fully understood. It is no doubt, however, that males competing for access to females during the reproduction season and, consequently, characterized by higher aggressiveness (i.e., dominant and subdominant individuals) usually do not maintain long-lasting pair bonds and do not exhibit care-giving activities. The main reproductive strategy of the males is related to the advantage of copulating with as many females as possible (Trivers, 1972). This reproductive strategy is obviously typical of most males in natural populations of the bank vole (Bujalska, 1994; Gromov, 2008). On the other hand, subordinate males with a lower level of aggressiveness which concede in competition with dominant males are more inclined to maintain longterm pair bonds and can participate in care of offspring. Such a reproductive strategy is obviously used by some males in populations of the bank vole (Gromov \& Osadchuk, 2013) as well as by many males in populations of the common vole (Gromov, 2013). Subordinate males exhibiting an alternative reproductive tactic associated with increased tolerance to the offspring and a higher level of parental responsiveness become more appropriate mates for the females if the specific social structure transforms, acquiring features of a familygroup social organization (Gromov, 2018). One can suggest that parental investment and, correspondingly, the reproductive success of the males displaying the subordinate behavior pattern may increase within the evolutionary transition to a family-group lifestyle.

Cooperation should be considered as one of indirect fitness benefits as well. Due to cooperation, the combined contribution of a male and a female to parental care appears much higher in social rodent species than in solitary or gregarious species with sole maternal care (Gromov, 2011a, 2011b, 2011c, 2013, 2014b). Cooperation in offspring care is most important, since the most complicated social rodent groups (i.e., family groups) do not form without it. In addition, the behavioral patterns of mating and parental responsiveness are formed in young male individuals due to the participation of the males in rearing their offspring (Gromov, 2013, 2014 b), which is extremely important in maintaining the family-group social structure. No doubt that inclusive 
fitness in the species with a family-group lifestyle increases mainly due to cooperation.

There is another aspect supporting the suggestion that inclusive fitness in rodents living in family groups could be higher than that of solitary or gregarious species, even though females of social species produce fewer offspring. In solitary and gregarious rodent species of the Holarctic fauna, young individuals disperse over a short period of time after weaning, and many of them perish before acquiring a suitable home range or mate (Anderson, 1989; Wolff, 1994; Solomon, 2003; Nunes, 2007; Solomon \& Keane, 2007; Gromov, 2008). A small part of the surviving young females reproduces by the end of the current breeding season giving birth to, as a rule, not more than one litter. Other surviving females rear their offspring during the next reproductive period, of course, in case they survive the winter. Therefore, the portion of successfully reproduced individuals after dispersal is not so large among solitary and gregarious rodent species. On the contrary, in species with a family-group lifestyle and delayed offspring dispersal, the potential reproductive success may be much higher. By remaining philopatric and associating with relative conspecifics, young individuals of a social rodent species can act cooperatively, especially during the severe winter period, thereby increasing their chances of survival. In many species of this category, young and subadult individuals exhibit various alloparental behaviors (Solomon \& Keane, 2007; Gromov, 2011c, 2013). Under these circumstances, the death rate of young individuals could be reduced to a minimum level. In other words, species with a family-group lifestyle produce fewer offspring, but ones of "better quality" in terms of fitness: a lower death rate of young individuals, along with their delayed dispersal, appears to enhance inclusive fitness of social rodents. Ultimately, potential reproductive success, and consequently, inclusive fitness in species with a familygroup lifestyle could be increased to a greater extent than in solitary and gregarious rodent species.

\section{Conclusion}

In the present study, a positive effect of biparental care on the survivorship and growth rates of young in the common vole and the bank vole is not revealed. In contrast, the presence of the male may negatively affect the survival of young in both species under study. Besides, a negative impact of the male presence on the growth rates of the offspring was found in the common vole. These findings suggest a reduced reproductive success, and, accordingly, fitness, in males of both species if they choose a reproductive strategy based on pair bonding and biparental care. The experimental situation could be considered as a model of behavior of breeding pairs in a rodent species whose social organization transforms into a family-group lifestyle. Despite the reduced reproductive success, inclusive fitness of rodent species with a family-group lifestyle compared to solitary and gregarious species could be maximized due to positive effect of other factors, especially due to cooperation.

ACKNOWLEDGMENTS.This work was supported by the Russian Foundation for Basic Research, project no. 15-04-00819. I am grateful to Yu.M. Kovalskaya for verifying the karyological identity of common voles used in this study.

\section{References}

Adler G.H., Wilson M.L. \& Derosa M.J. 1987. Effects of adults on survival and recruitment of Peromyscus leucopus // Canadian Journal of Zoology. Vol.65. P.2519-2544.

Ahroon J.K. \& Fidura F.G. 1976. The influence of the male on maternal behaviour in the Mongolian gerbil (Meriones unguiculatus) // Animal Behaviour. Vol.24. P.372-375.

Anderson P.K. 1989. Dispersal in rodents: A resident fitness hypothesis. Provo, UT: American Society of Mammologists. 289 p.

Bashenina N.V. 1962. [The ecology of the common vole and some features of its geographic variability.] Moscow: Moscow State University. 307 p. [In Russian]

Bashenina N.V. \& Meyer M.N. 1994. [Postnatal period. Growth // The common vole: Sibling species.] Moscow: Nauka Publ. P.242-245. [In Russian]

Bashenina N.V., Meyer M.N. \& Zorenko T.A. 1994. [Development // The common vole: Sibling species.] Moscow: Nauka Publ. P.253-266. [In Russian]

Blumstein D.T. \& Armitage K.B. 1998. Life history consequences of social complexity: a comparative study of ground-dwelling sciurids // Behavioral Ecology. Vol.9. P.8-19.

Bujalska G. 1994. Female and male territoriality in the bank vole // Jarman P.J. \& Rossitier A. (eds.). Animal societies: Individuals, interactions and organization. Kyoto: Kyoto Univ. Press. P.56-69.

Bujalska G. \& Saitoh T. 2000. Territoriality and its consequences // Polish Journal of Ecology. Vol.48. Suppl. P.37-49.

Calhoun J.B. 1962. The ecology and sociology of the Norway rat. Bethesda, Maryland. 264 p.

Cantoni D. \& Brown R.E. 1997. Paternal investment and reproductive success in the California mouse, Peromyscus californicus // Animal Behaviour. Vol.54. P.377-386.

Curtis J.T., Liu Y., Aragona B.J. \& Wang Z. 2007. Neural regulation of social behavior in rodents // Wolff J.O. \& Sherman P.W. (eds.). Rodent Societies: An Ecological \& Evolutionary Perspective. Chicago: Chicago Univ. Press. P.185-194.

De Jonge G. 1983. Aggression and group formation in the voles Microtus agrestis, M. arvalis and Clethrionomys glareolus in relation to intra- and interspecific competition // Behaviour. Vol.84. P.1-73.

Dudley D. 1974a. Paternal behaviour in the California mouse, Peromyscus californicus // Behavioral Biology. Vol.11. P.247-252.

Dudley D. 1974b. Contributions of parental care to the growth and development of the young Peromyscus californicus // Behavioral Biology. Vol.11. P.155-156.

Eisenberg J.F. 1966. The social organization of mammals // Handbook of Zoology Vol.10. P.1-192. 
Elwood R.W. \& Broom D.M. 1978. The influence of litter size and parental behaviour on the development of Mongolian gerbil pups // Animal Behaviour. Vol.26. P.438-454.

Emlen S.T. 1991. Evolution of cooperative breeding in birds and mammals // Krebs J.R. \& Davies N.B. (eds.). Behavioral Ecology. London: Blackwell. P.301-337.

Emlen S.T. 1994. Benefits, constraints and the evolution of the family // Trends in Ecology and Evolution. Vol.9. P.282-284.

Gerling S. \& Yahr P. 1979. Effect of the male parent on pup survival in Mongolian gerbils // Animal Behaviour. Vol.27. P.310-311.

Gromov V.S. 2008. [The spatial-and-ethological population structure in rodents.] Moscow: KMK Press. 582 p. [In Russian]

Gromov V.S. 2011a. Pair-bonding and parental care in cricetid rodents: A comparative study // Acta Theriologica. Vol.56. P.23-33.

Gromov V.S. 2011b. Biparental care, tactile stimulation, and evolution of sociality in rodents // Journal of Evolutionary Biology Research. Vol.3. P.33-43.

Gromov V.S. 2011c. Parental care, tactile stimulation and sociality evolution in rodents: Behavioural, physiological and developmental aspects. LAP LAMBERT Academic Publ. 104 p.

Gromov V.S. 2013. [Parental care in rodents: Ethological, physiological and evolutionary aspects.] Moscow: KMK Press. 338 p. [In Russian]

Gromov V.S. 2014a. Complicated social structure and the evolution of sociality in rodents: Cooperation as the main promoting factor. // Watson P. (ed.). Social Behavior: Evolutionary Pathways, Environmental Influences and Impairments. NY: Nova Science Publ. P.71-119.

Gromov V.S. 2014b. The early experience of tactile stimulation and its behavioral consequences related to socialization in mammals // Jaworski J.A. (ed.). Advances in Sociology Research. NY: Nova Science Publ. P.1-28.

Gromov V.S. 2018. The evolution of sociality in rodents: Environments and selective forces promoting grouping. LAP Lambert Acad. Publ. 163 p.

Gromov V.S. 2020a. Paternal care in rodents: Ultimate causation and proximate mechanisms // Russian Journal of Theriology. Vol.19. No.1. P.1-20.

Gromov V.S. 2020b. [Relationship between the social structure and potential reproductive success in muroid rodents (Rodentia, Myomorpha)]// Povolzhskii Journal of Ecology. No.1. P.15-30. [In Russian]

Gromov V.S. \& Osadchuk L.V. 2013. Parental care and testosterone in males of the bank vole (Myodes glareolus): Sensitization and androgenic stimulation of paternal behavior // Biology Bulletin. Vol.40. P.114-118.

Gromov V.S. \& Voznesenskaya V.V. 2013. Care of young, aggressiveness, and secretion of testosterone in male rodents: A correlation analysis // Biology Bulletin. Vol.40. P.463-470.

Gubernick D.J., Wright S.L. \& Brown R.E. 1993. The significance of father's presence for offspring survival in the monogamous California mouse, Peromyscus californicus // Animal Behaviour. Vol.46. P.539-546.

Gubernick D.J. \& Teferi T. 2000. Adaptive significance of male parental care in a monogamous mammal // Proceedings of Royal Society (Lond.). Ser.B. Vol.267. P.147-150.
Hamilton W.D. 1964. The genetical evolution of social behavior // Journal of Theoretical Biology. Vol.7. P.1-52.

Hartung T.G. \& Dewsbury D.A. 1979. Paternal behavior of six species of muroid rodents // Behavioral and Neural Biology. Vol.26. P.446-478.

Hoogland J.L. 1995. The black-tailed prairie dog: Social life of a burrowing mammal. Chicago: Chicago Univ. Press. 285 p.

Kleiman D.G. 1977. Monogamy in mammals // Quarterly Review of Biology. Vol.52. P.39-69.

Klippel J.A. 1979. Does the male gerbil parent (Meriones unguiculatus) contribute to pup mortality: A reply // Animal Behaviour. Vol.27. P.311-312.

Krebs J., Lambin X. \& Wolff J.O. 2007. Social behavior and self-regulation in murid rodents // Wolff J.O. \& Sherman P.W. (eds.). Rodent Societies: An Ecological \& Evolutionary Perspective. Chicago: Chicago Univ. Press. P.173-184.

Kurland J.A. \& Gaulin S.J.C. 1984. The evolution of male parental investment: effects of genetic relatedness and feeding ecology on the allocation of reproductive effort // Taub D.W. (ed.). Primate paternalism. NY: Van Nostrand Reinhold. P.259-308.

Lacey E.A. 2004. Sociality reduces individual direct fitness in a communally breeding rodent, the colonial tucotuco (Ctenomys sociabilis) // Behavioral Ecology and Sociobiology. Vol.56. P.449-457.

Lacey E.A. \& Sherman P.W. 1997. Cooperative breeding in naked mole rats: Implications for vertebrate and invertebrate sociality // Solomon N.G. \& French J.A. (eds.). Cooperative Breeding in Mammals. Cambridge: Cambridge Univ. Press. P.267-301.

Lacey E.A. \& Sherman P.W. 2007. The ecology of sociality in rodents // Wolff J.O. \& Sherman P.W. (eds.). Rodent Societies: An Ecological \& Evolutionary Perspective. Chicago: Chicago Univ. Press. P.243-254.

Lonstein J.S. \& De Vries G.J. 1999. Comparison of the parental behavior of pair-bonded female and male prairie voles (Microtus ochrogaster) // Physiology \& Behavior. Vol.66. P.33-40.

McCarty R. \& Southwick C.H. 1977. Patterns of parental care in two cricetid rodents, Onychomys torridus and Peromyscus leucopus // Animal Behaviour. Vol.25. P.945-948.

McGuire B. \& Bemis W.E. 2007. Parental care // Wolff J.O. \& Sherman P.W. (eds.). Rodent Societies: An Ecological \& Evolutionary Perspective. Chicago: Chicago Univ. Press. P.231-242.

McGuire B. \& Novak M. 1984. A comparison of maternal behaviour in the meadow vole (Mictotus pennsylvanicus), prairie vole (M. ochrogaster) and pine vole $(M$. pinetorum) // Animal Behaviour. Vol.32. P.1132-1141.

Nunes S. 2007. Dispersal and philopatry // Wolff J.O. \& Sherman P.W. (eds.). Rodent Societies: An Ecological \& Evolutionary Perspective. Chicago: Chicago Univ. Press. P.150-162.

Salo A.L. \& French J.A. 1989. Early experience, reproductive success, and development of parental behaviour in Mongolian gerbils // Animal Behaviour. Vol.38. P.693-702.

Schradin C. \& Pillay N. 2005. The influence of the father on offspring development in the striped mouse // Behavioral Ecology. Vol.16. P.450-455.

Sokal R.R. \& Rohlf F.J. 1995. Biometry: The Principles and Practice of Statistics in Biological Research. 3rd ed. NY: Freeman and Co. 582 p. 
Solomon N.G. 1991. Current indirect fitness benefits associated with philopatry in juvenile prairie voles // Behavioral Ecology and Sociobiology. Vol.29. P.277-282.

Solomon, N.G. 1993. Body size and social preferences of male and female prairie vole, Microtus ochrogaster // Animal Behaviour. Vol.45. P.1031-1033.

Solomon N.G. 2003. A reexamination of factors influencing philopatry in rodents // Journal of Mammalogy. Vol.84. P.1182-1197.

Solomon N.G. \& Keane B. 2007. Reproductive strategies in female rodents // Wolff J.O. \& Sherman P.W. (eds.). Rodent Societies: An Ecological \& Evolutionary Perspective. Chicago: Chicago Univ. Press. P.42-56.

Trivers R.L. 1972. Parental investment and sexual selection // Campbell B. (ed.). Sexual selection and descent of man. Chicago: Aldine. P.139-179.

Wang Z.X. \& Novak M.A. 1994a. Alloparental care and the influence of father presence on juvenile prairie voles, Microtus ochrogaster // Animal Behaviour. Vol.47. P.282-288.
Wang Z.X. \& Novak M.A. 1994b. Parental care and litter development in primiparous and multiparous prairie voles (Microtus ochrogaster) // Journal of Mammalogy. Vol.75. P.18-23.

Wolff J.O. 1994. More on juvenile dispersal in mammals // Oikos. Vol.71. P.349-352.

Wynne-Edwards K.E. \& Lisk R.D. 1989. Differential effects of paternal presence on pup survival in two species of dwarf hamsters (Phodopus sungorus and Phodopus campbelli) // Physiology \& Behavior. Vol.45. P.465-469.

Xia X. \& Millar J.S. 1988. Paternal behavior by Peromyscus leucopus in enclosures // Canadian Journal of Zoology. Vol.66. P.1184-1187.

Ylönen H. \& Viitala J. 1985. Social organization of an enclosed winter population of the bank vole Clethrionomys glareolus // Annales Zoologici Fennici. Vol.22. P.353-358.

Zorenko T.A. 1979. [The population structure of the common vole Microtus arvalis Pall. // Population dynamics and behavior of vertebrates in Latvian Republic.] Riga. P.79-101. [In Russian] 